Corresponding Author:

Annasari Mustafa

annasary@yahoo.com

Received: 23 September 2019 Accepted: 18 November 2019 Published: 22 December 2019

Publishing services provided by Knowledge

(c) Annasari Mustafa and Annisa Rizky Maulidiana. This article is distributed under the terms of the Creative Commons

Attribution License, which permits unrestricted use and redistribution provided that the original author and source are credited.

Selection and Peer-review under the responsibility of the ICHP Conference Committee.

\section{The Effectiveness of Nutrition Education about Local Specific Food-based Balanced Nutrition Recommendation on Dietary Intake Level and Anemia Status in Female Adolescents at the Hidayatullah Arrohmah Islamic Boarding School Malang}

\section{Annasari Mustafa ${ }^{1}$ and Annisa Rizky Maulidiana²}

${ }^{1}$ Nutrition Department, State Health Polytechnic of Malang, Indonesia

${ }^{2}$ School of Nutrition, Faculty of Medicine Universitas Brawijaya, Malang, Indonesia

\section{Abstract}

Background: Anemia is the biggest nutritional problem in Indonesian adolescents. One of the main risk factors is poor diet. Nutrition education as an intervention method has been shown to significantly improve healthy lifestyle and academic achievement in school-aged children. Objective: To analyze the effectiveness of nutrition education about local specific food-based balanced nutrition recommendation on the knowledge, dietary intake level, and anemia status of female adolescents. Methods: This study was a quasi-experimental research with pre- and post-test design. Eighty-three female students of the Hidayatullah Arrohmah Islamic Boarding School Malang were included as study participants. The nutrition education in the form of class counseling on balanced nutrition guidelines and healthy snacks was given for five consecutive months. Dietary consumption, knowledge, and hemoglobin level were measured before and after the intervention. Data analysis was done using paired t-test and Wilcoxon signed-rank test with $\mathrm{p}<0.05$ considered as significant. Results: There was a significant difference of the protein $(p=0.029)$ and $F e(p=0.021)$ intake level before and after the intervention, however, this result was not found in the vitamin $\mathrm{C}$ and folic acid intake. The nutritional knowledge as well as the hemoglobin level were increased significantly ( $p=0.001, p=0.04$, respectively). Conclusions: Nutrition education about local specific food-based balanced nutrition recommendation is very effective to increase knowledge, dietary intake (protein and iron), and hemoglobin levels in female adolescents.

Keywords: anemia, dietary intake, female adolescent, knowledge, nutrition education

\section{Introduction}

Anemia is one of the biggest nutritional problems in adolescence, especially in female 
women worldwide.[1] In 2011, Indonesia was ranked sixth out of 11 ASEAN countries, with approximately $22.5 \%$ of women in childbearing age affected by anemia.[2, 3] Anemia can be have many causes, including nutritional deficiencies, acute and chronic infection, blood loss, cancer, and hemoglobinopathy.[3] Anemic condition in adolescence that retain until pregnancy could increase the risk of perinatal maternal mortality, low birth weight baby, early labor and other disorders.[4]

Iron deficiency anemia is the most common type of anemia in female adolescents.[5, 6] Prior studies have shown that iron deficiency is due to lack of nutritional information, such as restricted diet to get an ideal body shape and inadequate intake of fruits and leafy green vegetables.[7] Thus, increasing the awareness of adolescents to have the right and balanced diet by choosing a healthy diet and lifestyle is very importance.

Nutrition education has been shown to improve healthy lifestyles, blood iron status indicators, and academic achievement in high school students.[3, 8] Several studies have been conducted to develop local specific food-based nutrition guidelines in developing countries.[9-12] This nutrition guideline is in accordance with the availability, affordability, and acceptance of food by the local community, so it provides a good opportunity to be followed and carried out on a daily basis.

Previous studies conducted in Indonesia were focused more on school students. However, there are many Islamic boarding schools in Indonesia, especially in Malang city, as a place to both study and live a daily life and never been researched before. Therefore, the aim of our study is to analyze the effectiveness of nutrition education about local specific food-based about Balanced Nutrition Guidelines on the knowledge level, dietary consumption, and anemia status of female adolescents in boarding school in Malang city, Indonesia.

\section{Materials and Methods}

\subsection{Study Design}

This study was a quasi-experimental research study with pre and post-test design performed during August to December 2017. Eighty-three female adolescents aged 16 to 18 years of Hidayatullah Arrohmah Boarding School Malang, Indonesia were incorporated in this study. The exclusion criteria were sick or in their period during the measurement day. If the respondent agreed to participate in this study, they had to hand in the signed informed consent. The study protocol was approved and registered 
No. $662 /$ KEPK-Polkesma/2017 by the Ethical Committee of the Health Polytechnic of Health Ministry Malang, Malang, Indonesia.

\subsection{Measurements}

\subsubsection{Nutritional knowledge level}

The intervention carried out in the form of counseling in class with information such as specific local food-based balanced nutrition recommendation, how to choose healthy food and snacks, as well as the danger of anemia for health. To know the knowledge level, we performed a multiple-choice test before and after the intervention. The score then categorized as: good, with $>80 \%$ right answers; moderate, with $60-80 \%$ right answers; or bad, with $<60 \%$ right answers.

\subsubsection{Dietary intake}

To measure the daily intake of respondent, $2 \times 24$ hour food recall was performed on non-consecutive days to obtain data on the types and quantities of food and beverages consumed by respondent. In addition, five days food records outside the recall days were collected to get more real consumption data. Then, the data entered into Nutrisurvey software (SEAMEO TROPMED RCCN-University of Indonesia, 2007) to estimate the daily intake of protein, iron, vitamin $\mathrm{C}$, and folic acid. The proportion at risk of inadequate intake was determined using IMAPP software, and the deficit nutrients could be seen from the data on consumption level.

\subsubsection{Anemia status}

The data of anemia status was collected by hemoglobin $(\mathrm{Hb})$ examination using portable digital analyzer, and categorized as anemia, if $\mathrm{Hb}<12 \mathrm{~g} / \mathrm{dl}$ or not anemia, if $\mathrm{Hb} \geq 12 \mathrm{~g} / \mathrm{dl}$.

\subsection{Statistical Analysis}

Data processing and analysis in this study was carried out using SPSS for Windows. The data was analyzed descriptively and presented as $n(\%)$. To see the effect of counseling, data with normal distribution were analyzed using paired t-test and for 
data with abnormal distribution using the Wilcoxon signed rank test. A p-value of 0.05 was considered as statistically significant.

\section{Result and Discussion}

\subsection{Nutritional Knowledge Level}

Overall, the level of knowledge before the intervention was intermediate, and after the intervention, the knowledge level was mostly good and no respondent had a bad score. There was a significant difference found between before and after the intervention $(p=0.001)$. The characteristics of respondents according to the level of knowledge before and after the intervention can be seen in Figure 1.

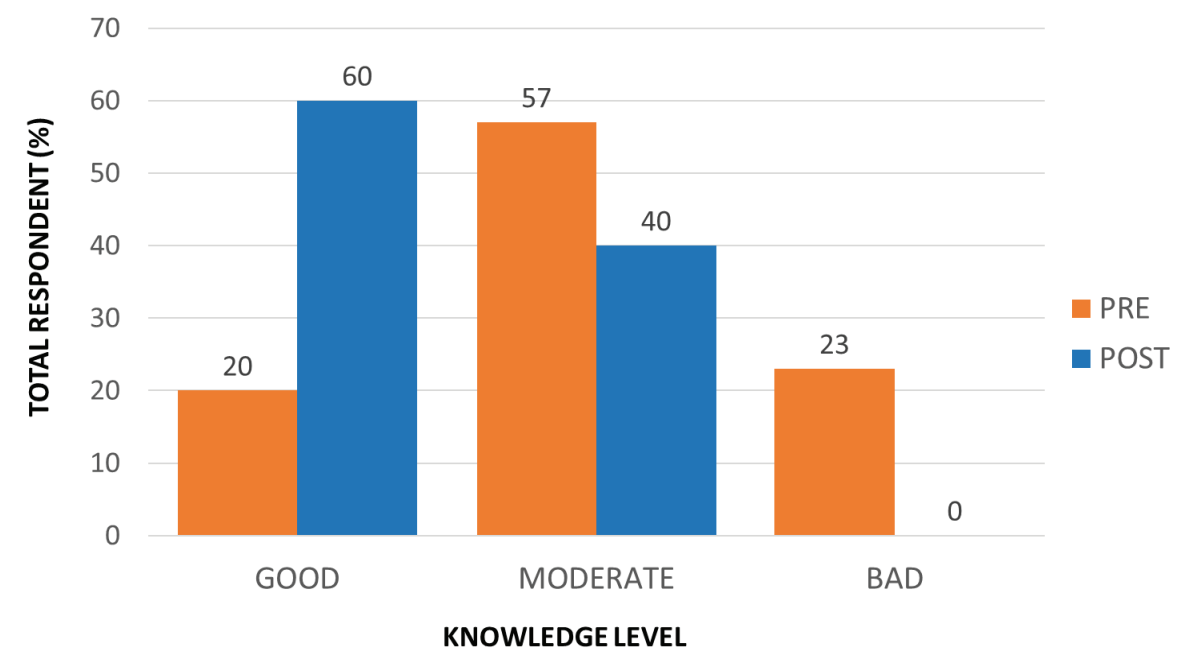

Figure 1: Knowledge Level of Respondent Before and After Intervention.

We found that nutrition education was effective to increase the level of respondents' knowledge of healthy lifestyle and anemia. The results of this study were in line with Ariyanti study (2017) conducted at Cemorokandang 1 Elementary School in Malang, showed that nutritional education could increase the level of nutritional knowledge.[13] Moreover, Kusuma study (2014) also stated that there was an effect of health education about anemia on the level of knowledge in female students of Muhammadiyah 5 High School in Yogyakarta.[1, 4]

From the test results, most of our respondents did not know the normal $\mathrm{Hb}$ level in female adolescent so there were still many answered incorrectly. Nutritional knowledge is about the function of food to reach optimal health, including the proper daily food selection and intake to provide all the nutrients needed for a normal body function as well as the effect if the intake is deficient or excessive. The selection and consumption of 
food affect a person nutritional status. Optimal nutritional status occurs when the body gets enough nutrients needed by the body. Poor nutritional status occurs when there is a deficiency of one or more essential nutrients. While overnutrition occurs when there is an excessive amount of nutrients. This malnutrition condition could cause various harmful effects.[1, 5]

\subsection{Dietary Intake}

Dietary intake was analyzed on the following nutrients: protein, iron, vitamin C, and folic acid. The different between before and after intervention can be seen in Figure 2 .

For protein, before the intervention majority of respondents (66\%) were in deficit (very low, medium low, and low) level. However, the protein intake was increasing after the intervention, showed by $87 \%$ respondents were in normal level. Moreover, we found a statistically significant difference of protein intake before and after intervention $(p=0.029)$. As for iron, about $92 \%$ and $2 \%$ respondents were in very low and low intake. However, after the intervention this number decreased to $86 \%$ and $11 \%$, respectively. This result was also proven by a significant difference $(p=0.021)$.

Overall, before the intervention most respondents were in the very low intake (61\%). And after the intervention, this number got higher to $68 \%$. However, there was no significant difference found between before and after intervention $(p=0.18)$. Same pattern was also found in folic acid intake. Before intervention there were $98 \%$ respondents in very low intake level, and this number increased to $100 \%$ after intervention. Similarly, no significant difference was found $(p=0.903)$.

The significant difference of protein and iron intake before and after intervention was in accordance with prior studies. Shefaya et al., 2017) found a significant difference on protein and iron intake level before and after nutrition counseling in Teuku Umar High School students, Semarang.[16] An increase in protein intake was also found in elementary students of Cemorokandang 1 Elementary School in Malang.[13] Other study also stated that nutrition education was effective to increase iron intake on female adolescents about $15.5 \mathrm{mg}(p<0.001) \cdot[17]$

In this study, there was no effect of the nutrition education on the vitamin $C$ intake. This result was also found in previous study in Semarang.[16] This result could be due to respondents had an inadequate intake of fruits and vegetables which are a high source of vitamin $C$ and folic acid. The respondents prefer snacks and fast foods rather than fruits and vegetables. Nevertheless, adequate intake of vitamin $C$ and folic acid can help the body to absorb iron. If the intake level of protein, iron, vitamin C, and folic 


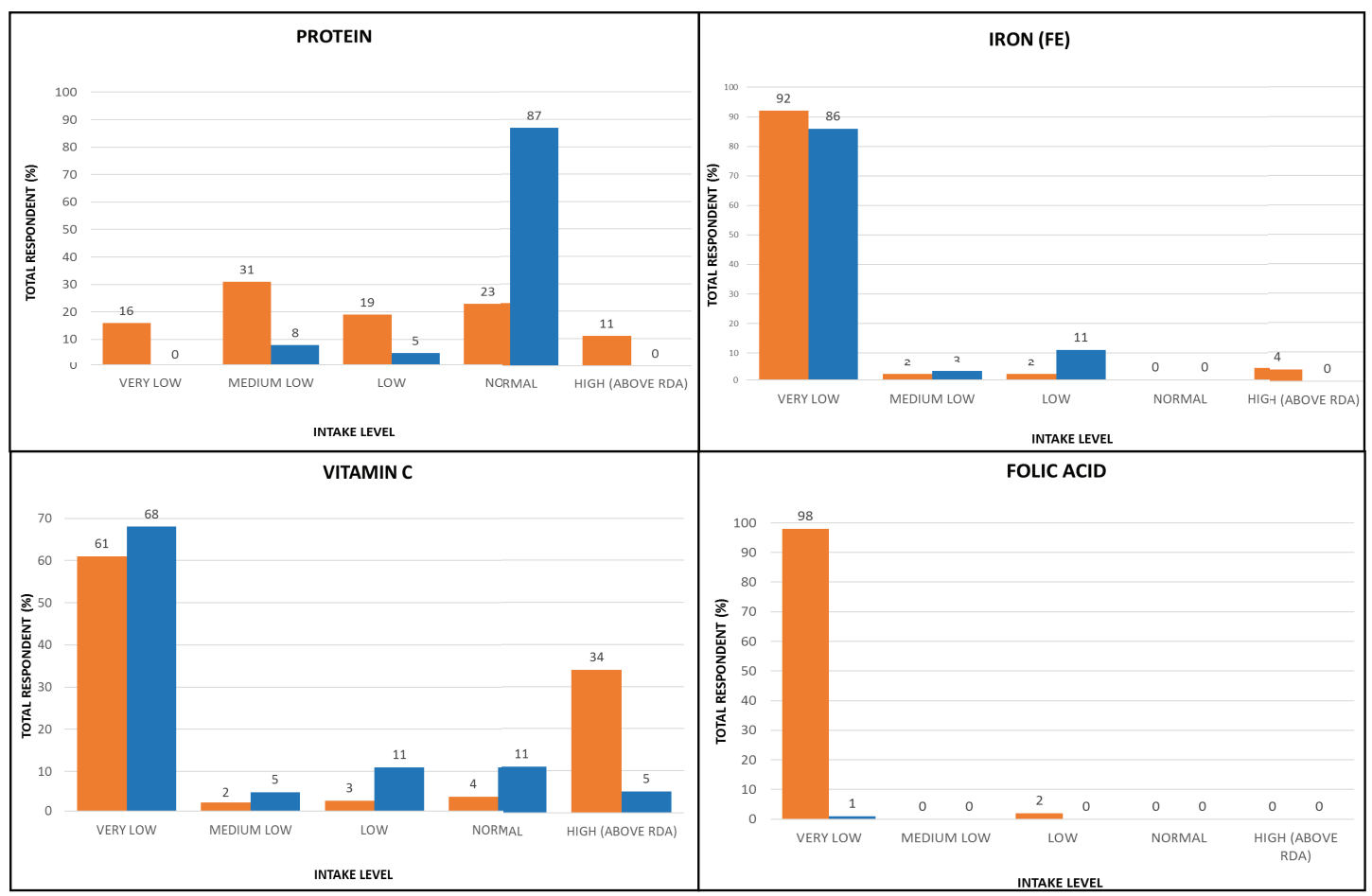

Figure 2: Dietary Intake Level of Respondent Before and After Intervention (clockwise: protein, iron, folic acid, and vitamin C).

acid are adequate, the hemoglobin level will increase.[15] Nutrition education is very important in adolescence, to make them able to understand the importance of food and nutrition so they eager to have a healthy lifestyle. However, a longer time and strong desire is needed to change the usual habit, such as in healthy attitude and practice.

\subsection{Anemia Status}

Before the intervention, about $23 \%$ respondents had anemia and the rest of them (77\%) was not anemic. After the intervention, the anemia proportion was decreased to $22 \%$. We found a significant difference of anemia status before and after intervention, means that there is a significant effect of nutrition education on hemoglobin level.

The result of this study was in line with prior study demonstrated that nutrition education was significantly increased hemoglobin level by $1.3 \mathrm{~g} / \mathrm{dL}$ in anemic female adolescents at Simo 1 High School Boyolali $(p<0.001)$.[17] Other study also suggested that hemoglobin level in anemia patients in Sukoharjo Regency was increased after treated with nutrition education.[18] 


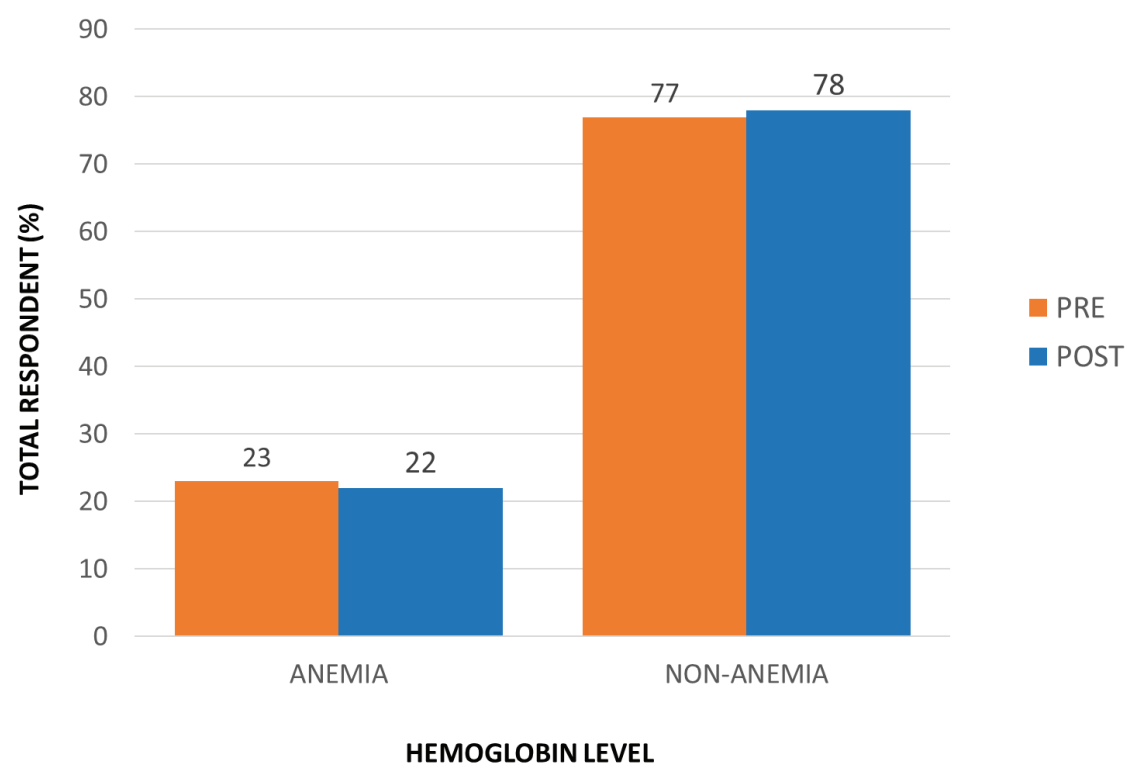

Figure 3: Anemia Status of Respondent Before and After Intervention.

\section{Conclusion}

Nutrition education about local specific food-based balanced nutrition recommendation is very effective to increase the nutritional knowledge, dietary intake (protein and iron), and hemoglobin level in female adolescents at the Hidayatullah Arrohmah Islamic Boarding School, Malang.

\section{Acknowledgments}

This study is fully funded by Health Polytechnic of Health Ministry Malang. We gratefully thankful to Hidayatullah Arrohmah boarding school, study participants, and the enumerators.

\section{Conflict of Interest}

There is no conflict of interest to declare.

\section{References}

[1] World Health Organization (WHO). The database on anemia includes data by country on prevalence of anemia and mean hemoglobin. Geneva, Switzerland. WHO, 2008. 
[2] Stevens GA, Finucane MM, De-Regil LM, et al. Global, regional, and national trends in haemoglobin concentration and prevalence of total and severe anaemia in children and pregnant and non-pregnant women for 1995-2011: a systematic analysis of population-representative data. The Lancet Global Health 2013; 1(1): e16-e25.

[3] WHO. Prevention of Iron Deficiency Anaemia in Adolescents: Role of Weekly Iron Folic Acid Supplementation: WHO SEARO; 2011.

[4] Van-den RB, Broak NR. Etiology of anemia in pregnancy in South Malawi. Am J Clin Nutr. 2000; 72: 247S-256S.

[5] WHO. Worldwide prevalence of anaemia 1993-2005: WHO global database on anaemia. 2008.

[6] Delisle H, Chandra-Mouli V, de Benoist B. Should Adolescents Be Specifically Targeted for Nutrition in Developing Countries: To Address Which Problems, and How? World Health Organization/International Nutrition Foundation for Developing Countries Available at http://www who int/childadolescenthealth/New_Publications/NUTRITION/Adolescent_nutrition_paper pdf 2000.

[7] Khasanah, FU. Membangun Kesadaran Remaja Berperilaku Sehat. 2011.

[8] Alaofè H, Zee J, Dossa R, O'Brien HT. Education and improved iron intakes for treatment of mild iron-deficiency anemia in adolescent girls in southern Benin. Food and nutrition bulletin 2009; 30(1): 24-36.

[9] Kersting M, Alexy U, Clausen K. Using the concept of food based dietary guidelines to develop an optimized mixed diet (OMD) for German children and adolescents. Journal of pediatric gastroenterology and nutrition 2005; 40(3): 301-8.

[10] Ferguson EL, Darmon N, Fahmida U, Fitriyanti S, Harper TB, Premachandra IM. Design of optimal food-based complementary feeding recommendations and identification of key "problem nutrients" using goal programming. The Journal of nutrition 2006; 136(9): 2399-404.

[11] Maillot M, Vieux F, Amiot MJ, Darmon N. Individual diet modeling translates nutrient recommendations into realistic and individual-specific food choices. The American journal of clinical nutrition 2010; 91(2): 421-30.

[12] Fahmida U, Mustafa A, Adhiyanto C. Panduan Gizi Seimbang berbasis pangan lokal hasil analisa program linier untuk menurunkan anemia pada remaja putri: Pretesting dan baseline Survey. Laporan Penelitian. Seameo Recfon 2016.

[13] Ariyanti, NA. Pengaruh Edukasi Terhadap Tingkat Pengetahuan, Tingkat Konsumsi Zat Gizi (Protein, Vitamin C dan Zat Besi), dan Kadar Hemoglobin Terkait dengan Kejadian Anemia Anak Sekolah Dasar Di SDN Cemorokandang 1 Kota Malang. Skripsi 2017. Poltekkes Kemenkes Malang. 
[14] Kusuma NI and Kartini F. Pengaruh Pendidikan Kesehatan Anemia pada Remaja Putri terhadap Tingkat Pengetahuan dan Sikap dalam Mencegah Anemia pada Siswi Kelas X SMA Muhammadiyah 5 Yogyakarta. Skripsi thesis 2014, STIKES 'Aisyiyah Yogyakarta.

[15] Almatsier S. Prinsip Dasar IImu Gizi. Gramedia Pustaka Utama 2011, Jakarta.

[16] Sefaya, NR. Pengaruh Pendidikan Gizi terhadap Pengetahuan Gizi dan Tingkat Konsumsi Zat Gizi Terkait Pencegahan Anemia Remaja (Studi pada Siwa Kelas XI SMA Teuku Umar Semarang). Jurnal Kesehatan Masyarakat 2017. Universitas Diponegoro.

[17] Marfuah D, Kusudaryati DPD. Efektifitas Edukasi Gizi terhadap Perbaikan Asupan Protein dan Kadar Hemoglobin pada Remaja Putri. Prosiding Semnas Gizi 2017. Universitas Muhammadiyah Surakarta.

[18] Zulaekah S and Widajanti L. 2010. Pengetahuan Gizi dan Kadar Hemoglobin Anak Sekolah Dasar Penderita Anemia setelah Mendapatkan Suplementasi Besi dan Pendidikan Gizi. Kesmas: National Public Health Journal 2010; 5(1): 36-41. 